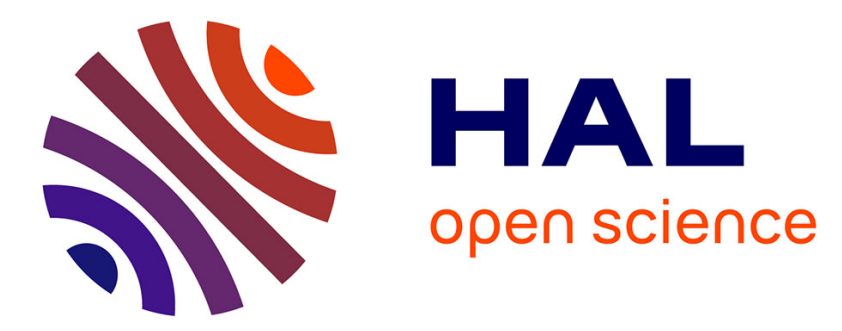

\title{
Sensitivity analysis of X-band SAR to wheat and barley leaf area index in the Merguellil Basin
}

\author{
Giacomo Fontanelli, Simonetta Paloscia, Mehrez Zribi, Aicha Chahbi
}

\section{To cite this version:}

Giacomo Fontanelli, Simonetta Paloscia, Mehrez Zribi, Aicha Chahbi. Sensitivity analysis of X-band SAR to wheat and barley leaf area index in the Merguellil Basin. Remote Sensing Letters, 2013, 4 (11), 1107-1116, http://dx.doi.org/10.1080/2150704X.2013.842285. hal-00906743

\section{HAL Id: hal-00906743 https://hal.science/hal-00906743}

Submitted on 21 Nov 2013

HAL is a multi-disciplinary open access archive for the deposit and dissemination of scientific research documents, whether they are published or not. The documents may come from teaching and research institutions in France or abroad, or from public or private research centers.
L'archive ouverte pluridisciplinaire HAL, est destinée au dépôt et à la diffusion de documents scientifiques de niveau recherche, publiés ou non, émanant des établissements d'enseignement et de recherche français ou étrangers, des laboratoires publics ou privés. 


\title{
Sensitivity analysis of X-band SAR to wheat and barley Leaf Area Index in the Merguellil Basin
}

\author{
Giacomo FONTANELLI*广, Simonetta PALOSCIA ${ }^{\dagger}$, Mehrez ZRIBI ${ }^{\ddagger}$, Aicha CHAHBI $^{\S}$ \\ ${ }^{\dagger}$ Institute of Applied Physics (CNR- IFAC), 50019, Firenze, I \\ Centre d'Etudes Spatiales de la Biosphère UMR 5126 (UPS, CNRS, CNES, IRD), \\ 31401, Toulouse Cedex 4, FR \\ ${ }^{\S}$ INAT, 1082, Tunis-Mahrajène, TN \\ *Email :g.fontanelli@ifac.cnr.it
}

Remote sensing of vegetation by using active microwave sensors is important for the management of land and water resources. Microwave radiation at X-band penetrates only the upper part of the canopy; thus, radar backscattering comes mainly from the top vegetation layer, making the scattering from soil almost negligible. Fourteen in-situ measurement campaigns were carried out during which sixteen SAR images of COSMO-SkyMed and TerraSAR-X were acquired on the test site of Merguellil Basin, in the center of Tunisia, from March to May 2012. A clear sensitivity of the backscattering coefficient, measured by both sensors, to the leaf area index (LAI) of green plants of wheat and barley (at both HH- and VVpolarizations) was observed, and it did not seem to be greatly affected by the variations in soil moisture, even in $\mathrm{HH}$ polarization. As expected, the sensitivity to LAI of dry plants was, instead, almost negligible. The decreasing trend of backscattering as vegetation grows, which has already been observed in past investigations, also at lower frequencies, was confirmed. Due to the similar geometry and dimensions of the two crop types, none of the sensors succeeded in separating the two crop types.

\section{Introduction}

Remote sensing of vegetation using active microwave sensors can provide significant help in investigating the Earth's surface at different spatial scales and with very frequent revisiting times. Synthetic Aperture Radar (SAR) sensors have proved to be the most useful platforms for a high-resolution surface analysis (e.g. Baronti et al. 1995, Moran et al. 2000, Shi et al. 1997).

Several SAR satellites have been launched recently, and other missions are planned for the near future: e.g. COSMO-SkyMed (COnstellation of small Satellites for Mediterranean basin Observation) (Italy), TerraSAR-X (Germany), SeoSAR (Satélite Español de Observación SAR), Sentinel-1 (European Space Agency), Radarsat RCM (Radarsat Constellation Mission) (Canada), Kompsat 5 (KOrean MultiPurpose SATellite) (Korea), RISAT (Radar Imaging Satellite) (India).

From the analysis of these data, significant information on soil and vegetation parameters was retrieved, and therefore these techniques are being increasingly used to manage land and water resources for agricultural applications, such as leaf water potential (Maltese et al., 2011), soil water content (Ferrazzoli et al., 1997; Paloscia et al., 2004; Paloscia et al., 2008; Aubert et al., 2011), irrigation water management (AlRumkhani and Din, 2004; Cammalleri et al., 2012; Dente et al., 2008; Hadria et al., 2010) and flood prediction (Aubert et al., 2003; Bates, 2004; Mason et al., 2010).

COSMO-SkyMed (CSK) and TerraSAR-X (TSX) are two European SAR missions, the first one is supported by the Italian Space Agency (ASI) and the second one by the German Aerospace Center (DLR). Both constellations consist of an X-band SAR 
satellite-borne sensor, in multiple polarizations and angular configurations, capable of achieving very high temporal and spatial resolutions, which can provide suitable data for an operative crop monitoring and for all the applications related to the precision farming (Balenzano et al., 2011; Bouman and van Kasteren, 1990; Capodici et al., 2013; Fieuzal et al., 2013; Santi et al. 2012).

Mapping vegetation using X-band sensors has, nonetheless, certain limitations (Ulaby et al. 1986), because radiation at X-band penetrates only into the upper part of the canopy, thus relating the radar backscattering coefficient $\left(\sigma^{\circ}\right)$ to the top layer of vegetation. This weak penetration makes the contribution to the scattering from soil surface almost negligible, therefore limiting the effect of soil moisture under vegetation on the measurement.

A consistent research activity was carried out by IFAC-CNR (Institute of Applied Physics of the National Research Council), CESBIO (Centre d'Etudes Spatiales de la BIOsphère) and INAT (Institut National d'Agronomie de Tunisie) groups to explore the sensitivity of $\sigma^{\circ}$ measured from soil and vegetation by using data from these two satellites (e.g. Anguela et al., 2010; Aubert et al., 2011; Santi et al., 2011 and 2012; Paloscia et al., 2012; Pettinato et al., 2013).

In this letter, we focused our attention on the relationships between $\sigma^{\circ}$ and leaf area index (LAI) of wheat and barley crops on the semi-arid agricultural test-site of the Merguellil Basin (Tunisia), which have been carefully investigated by using a high number of satellite images and a consistent dataset of accurate ground measurements.

\section{Methods}

\subsection{Description of the test site}

The test Site of Merguellil (Zribi et al., 2011) is a station in the Kairouan plain characterized by a semi-arid $\left(35.57^{\circ} \mathrm{N} ; 9.87^{\circ} \mathrm{E}\right)$. The rainfalls are very variable, from 200 to $550 \mathrm{~mm}^{\text {year }}{ }^{-1}$.

The area has an agricultural profile that has been significantly altered by extensive water and soil conservation works. In this plain, agriculture represents the main water use and depends on extractions from the local aquifer. The main crops are cereals, olives, tomatoes, melons, water melons, chili pepper.

The Merguellil catchment has limited and fragile water resources, and faces increasing water demand, which has led to an overexploitation of the groundwater.

\subsection{Measurement campaigns}

Fourteen measurement campaigns were carried out during the period from March to June 2012, as shown in table 1.

Field measurements were carried in 25 agricultural fields of average dimensions of about 4 ha, gathering 4/6 samples per field, according with their dimensions. Ground measurements consisted of plant height $(\mathrm{cm})$ and density $\left(\right.$ plants $\mathrm{m}^{-2}$ ), stem diameter $(\mathrm{cm})$, number of leaves per plant and their dimensions, angle of insertion of the leaves, plant biomass $\left(\mathrm{kg} \mathrm{m}^{-2}\right)$, leaf area index (LAI, $\left.\mathrm{m}^{2} \mathrm{~m}^{-2}\right)$, and plant moisture $\left(M_{\mathrm{v}} \%\right.$, computed as the difference between fresh and dry plant weight normalized to the fresh weight). Volumetric soil moisture content (SMC, $\mathrm{cm}^{3} \mathrm{~cm}^{-3}$ ) was measured by using a portable ThetaProbe, and soil surface roughness by using a needle profilometer. Leaf 
area index (LAI) was selected as the parameter related to vegetation (wheat and barley) growth. An indirect method for LAI determination based on hemispherical canopy photography (HCP) was selected, in order to obtain faster and easier in-situ measurements. HCP is a technique for studying plant canopies via photographs acquired through a hemispherical (fisheye) lens from beneath the canopy (oriented towards zenith) or placed above the canopy looking downwards (Jonckheere et al., 2004).

\subsection{SAR images}

Sixteen SAR images were acquired during the period from March to May 2012 (eight from TSX and eight from CSK). The characteristics of these images are shown in table 2 . The backscattering coefficient $\left(\sigma^{\circ}\right)$ values derived from eight SAR images were correlated to the corresponding in-situ measurements; therefore, only these images were used in this letter.

The available single-look images were multilooked with a window size of 5 pixels $\times 5$ pixels in range and azimuth direction, in order to reduce speckle. The TSX Spotlight images were delivered already multilooked.

Each image was radiometrically calibrated using the software SARScape@4.4 (Holecz et al., 1993). During the same processing step, SARScape $\odot$ was also used to georeference the images, using SRTM-4 (Shuttle Radar Topography Mission) (Kropatsch and Strobl, 1990; Frei et al., 1993; Meier et al., 1993).

In spite of the georeferencing process, some discrepancies may still have remained between the different SAR sensors, and each image was thus co-registered to an optical SPOT (Système Pour l'Observation de la Terre) image, with $10 \mathrm{~m}$ spatial resolution, which was used as a reference.

The images, correctly georeferenced and co-registered, have a common square pixel dimension of $10 \mathrm{~m}$.

\section{Results and discussion}

The analysis was carried out by directly relating $\sigma^{\circ}$ values at both $\mathrm{HH}$ and VV polarizations to LAI of wheat and barley measured on ground. We reported the results obtained at $\mathrm{HH}$ and VV polarizations separately. For one date, 16 April, both TSX and CSK satellites flew over the site and their data have been compared, although they have been acquired with a slightly different incidence angle (TSX: $35^{\circ}$, and CSK: $45^{\circ}$ ). A significant variability was observed in the LAI measurements, at each date, due to the high heterogeneity of the fields in terms of plants density, phenological stages and plants geometry. Fields irrigated during the satellites passes were excluded from the analysis.

A general decreasing trend was noted in the $\sigma^{\circ}$ as the wheat and barley plants grew, as has already been observed at lower frequencies (i.e. C-band) in other experiments (e.g. Macelloni et al., 2001). This behavior is typical of narrow-leaf crops (such as wheat, barley, alfalfa) at high frequencies, mainly at $\mathrm{VV}$ polarization, due to the high absorption of the vertical structure of thin and dense stems (Macelloni et al., 2001; Paloscia et al., 2012).

The effect of soil and vegetation moisture was also investigated. 


\subsection{Results of the analysis of the $\mathrm{HH}$ polarization data}

The TSX $\sigma^{\circ}$ values of the images collected in March (14 and 25 March 2012) were correlated with LAI data of the corresponding field measurement campaigns. During this period, the plants underwent very fast growth. On 14 March the vegetation had an average height of 30-40 cm, while on 25 March the height reached $80-100 \mathrm{~cm}$, and some plants already had a small ear (heading phase). The average soil moisture content was $22 \%$ on 14 March and $11 \%$ on 25 March.

In figure 1 the $\sigma^{\circ}$ values in $\mathrm{HH}$ polarization at the two dates are shown as a function of LAI. The regression equations obtained for each date are the following:

$$
\begin{array}{ll}
\sigma_{\mathrm{HH}}^{\circ}=0.62(\mathrm{LAI})-8.94 & \text { (14 March 2012; TSX) } \\
\sigma_{\mathrm{HH}}^{\circ}=0.64(\mathrm{LAI})-9.69 & \text { (25 March 2012; TSX) } \\
\sigma_{\mathrm{HH}}^{\circ}=0.60(\mathrm{LAI})-9.39 & \text { (14 and 25 March 2012; TSX) }
\end{array}
$$

The determination coefficient, $R^{2}$, is 0.82 for 14 March 2012, 0.60 for 25 April 2012 while for both datasets cumulated is 0.61 . It can be observed that there was a clear decreasing trend as the LAI increases, with a generally rather high sensitivity to LAI, especially on 14 March, probably because the vegetation conditions inside the fields were more homogeneous. The $p$-value for both datasets resulted to be $<0.05$. The effect of SMC variations was checked and found to be very low. The direct correlation between $\sigma^{\circ}$ and SMC produced, in fact, $R^{2}<0.25$, in spite of the general rather high sensitivity of $\mathrm{HH}$-polarization to soil moisture, even on moderately vegetated soils.

\subsection{Results of the analysis of the $V V$ polarization data}

The vegetation reached its maximum growth during the first week of April 2012, when the Vegetation Moisture $\left(M_{\mathrm{v}}\right)$ was $\cong 85 \%$. In this period two images from CSK and TSX, both in VV polarization, were acquired, on 8 and 5 April, respectively. The average soil moisture content was $12 \%$ on 5 April. On 8 April no data regarding soil moisture were available, but the value should have been reasonably very close to that of 5 April. By comparing the datasets separately for each date, the obtained experimental relationships are the following:

$$
\begin{array}{ll}
\sigma_{\mathrm{VV}}^{\circ}=0.76(\mathrm{LAI})-10.41 & \text { (5 April 2012; TSX) } \\
\sigma_{\mathrm{VV}}^{\circ}=0.83 \text { (LAI)-11.50 } & \text { (8 April 2012; CSK) }
\end{array}
$$

It can be noted that, also in this case, there was a clear decreasing trend as the LAI increases for both sensors, with rather high determination coefficients $\left(R^{2}=0.67\right.$ for CSK and $R^{2}=0.79$ for TSX) and similar slopes $(\cong 0.8)$. In some fields, the presence of a young ear was visible, but none of the sensors was able to detect it. The $p$-value is $<0.05 . M_{\mathrm{v}}$ remains almost constant for the considered period, since its values drop down to 0.5-0.6 only in the senescence phase, which is a period not investigated in this analysis.

On 16 April, both satellites flew over the site. In this period, the vegetation underway the ripening phase. The average SMC was $18 \%$. The $\sigma^{\circ}$ values of both TSX and CSK versus LAI of barley and wheat crops are shown in figure 2. The regression equations are as follows: 


$$
\begin{array}{ll}
\sigma_{\mathrm{VV}}^{\circ}=0.81(\mathrm{LAI})-9.97 & \text { (16 April 2012; TSX) } \\
\sigma_{\mathrm{VV}}^{\circ}=0.79 \text { (LAI)-11.85 } & \text { (16 April 2012; CSK) }
\end{array}
$$

Although the CSK images were acquired with a higher incidence angle $\left(45^{\circ}\right)$ than that of TSX $\left(35^{\circ}\right)$, the sensitivity to LAI was almost the same for both TSX and CSK ( $R^{2}=0.70$ for $\mathrm{CSK}$ and $R^{2}=0.76$ for TSX). It should be noted that the average backscattering level of TSX was about $2 \mathrm{~dB}$ higher than CSK, as it has already been reported in Paloscia et al. (2012), Santi et al. (2012), and Pettinato et al. (2013). In any case, the difference between the incidence angles would cause an opposite behaviour, with CSK data showing higher level of backscatter.

In figures 3 and 4 , the $\sigma^{\circ}$ values in VV polarization, collected for all the available dates (5, 8, and 16 April 2012) are represented as a function of LAI for both sensors. The sensitivity of $\sigma^{\circ}$ to SMC under dense vegetation cover was almost negligible, with very low $R^{2}(<0.10)$. The black continuous lines represent the regressions relative to 8 and 16 April 2012 for CSK and 5 and 16 April 2012 for TSX, respectively, and are shown below:

$$
\begin{array}{ll}
\sigma_{\mathrm{VV}}^{\circ}=0.81(\mathrm{LAI})-11.70 & \text { (8 and } 16 \text { April 2012; CSK) }(8) \\
\sigma_{\mathrm{VV}}^{\circ}=0.79(\mathrm{LAI})-10.16 & \text { (5 and } 16 \text { April 2012; TSX) }(9)
\end{array}
$$

The sensitivity to LAI of TSX in VV-polarization results to be slightly higher than CSK $\left(R^{2}=0.80\right.$ and $\left.R^{2}=0.69\right)$. Combining all data of TSX and CSK of 5, 8 and 16 April, the sensitivity to LAI in VV-polarization decreases, but is still present, showing $R^{2}=0.62$ :

$$
\sigma_{\mathrm{VV}}^{\circ}=0.80 \text { (LAI)-10.95 (5, } 8 \text { and } 16 \text { April 2012; TSX+CSK) }
$$

At the end of April 2012, the barley and wheat plants were drying rapidly, and therefore the correlation between LAI and plant water content decreased. Thus, the X-band $\sigma^{\circ}$ of both CSK and TSX sensors showed a lower correlation to LAI, since the radar signal is physically more related to the water content.

The average SMC was 9\% on 27 April. No data regarding soil moisture are available on 24 April, although the value was likely close to that of 27 April.

A further LAI measurement campaign was carried out on 4 May 2012, when vegetation was senescent. It was therefore impossible to obtain reliable LAI values using the hemispherical canopy photography (HCP) technique. In fact, this technique produced reliable LAI measurements for values higher than 0.2 only (Demarez et al. 2008).

\section{Conclusions}

Although X-band is not the best frequency for monitoring soil and vegetation parameters, due to the weak penetration into canopy and soils, a rather high sensitivity of the $\sigma^{\circ}$ of CSK and TSX sensors to wheat and barley LAI (at both HH and VV polarizations) was observed during this research work.

First of all, the decreasing trend of $\sigma^{\circ}$ as the vegetation grew, typical of narrow-leaf crops (e.g. wheat, barley and alfalfa) and caused by the strong absorption of thin and dense vertical stems (Macelloni et al. 2001, Santi et al. 2012), was confirmed.

In general, we observed that the determination coefficients of the regression equations between $\sigma^{\circ}$ and LAI were higher than 0.6-0.7, with a slope of about 0.8 . 
The $p$-value obtained for all correlations is always $<0.05$, due to the significant amount of experimental data and the rather high determination coefficients.

The sensitivity to the LAI of almost senescent plants was instead not significant, since the backscatter is mainly related to the total amount of water present in vegetation (and therefore to the plant water content), which considerably decreases in the ripening phase. $M_{\mathrm{v}}$ remains almost constant for the considered period, since its values drop down to $0.5-0.6$ only in the senescence phase, which is a period not investigated in this analysis.

Although CSK images were acquired with a higher incidence angle $\left(45^{\circ}\right)$ with respect to TSX $\left(35^{\circ}\right)$, the sensitivity of both the sensors to the LAI was almost the same, and the average $\sigma^{\circ}$ level of TSX was found to be slightly higher (by about $2 \mathrm{~dB}$ ) than CSK, as it has already pointed out in previous investigations. Moreover, due to the strong similarity in geometry and dimensions of the two crop types, none of the sensors (TSX and CSK) was able to separate the barley from the wheat crops.

The sensitivity of $\sigma^{\circ}$ in VV and HH polarizations to LAI during the observation period, at the end of which the vegetation was completely developed, did not seem to be greatly affected by the variations in soil moisture and remained high, with $R^{2}>0.70$. The effect of soil moisture was investigated and it was found, as expected, to be weak in March and almost negligible in April and May, when the vegetation was fully developed. The sensitivity to SMC was very low even in $\mathrm{HH}$ polarization, which is the most sensitive mode to this parameter.

\section{Acknowledgments}

This research was partially supported by the Italian Space Agency (ASI) through the Hydro-Cosmo 1720 project. ASI also provided the COSMO-SkyMed X-band SAR images necessary for the analysis. TerraSAR-X images were obtained through the CAL1279. The authors would like to thank IRD staff for their kind assistance I gathering and interpreting ground parameters.

\section{References}

AL-RUMKHANI, Y.A. and DIN, S.U., 2004, Use of remote sensing for irrigation scheduling in arid lands of Saudi Arabia. Journal of the Indian Society of Remote Sensing, 32, pp. 225 - 233.

ANGUELA, T.P., ZRIBI, M., BAGHDADI, N. and LOUMAGNE, C., 2010, Analysis of local variation of soil surface parameters with TerraSAR-X radar data over bare agricultural fields, IEEE Geoscience and Remote Sensing, Transaction on, 48,2, pp. $874-881$.

AUBERT, D., LOUMAGNE, C. and OUDIN, L. 2003, Sequential assimilation of soil moisture and streamflow data in a conceptual rainfall runoff model, Journal of Hydrology, 280, pp. 145 - 161.

AUBERT, M., BAGHDADI, N., ZRIBI, M., DOUAOUI, A., LOUMAGNE, C., BAUP, F., EL HAJJ, M. and GARRIGUES, S., 2011, Analysis of TerraSAR-X data sensitivity to bare soil moisture, roughness, composition and soil crust, Remote Sensing of Environment, 115, 8, pp. 1801 - 1810.

BALENZANO, A., SATALINO, G., BELMONTE, G., D’URSO, G., CAPODICI, F., IACOBELLIS, V., GIOIA, A., RINALDI, M., RUGGIERI, S. and MATTIA, F., 2011, On the Use of Multi-Temporal Series of Cosmo-SkyMed, Data for Landcover Classification and Surface Parameter Retrieval over Agricultural Sites. In Geoscience and Remote Sensing Symposium (IGARSS), IEEE International Proceedings of, 24 - 29 July 2011, Vancouver, BC, Canada.

BARONTI S., DEL FRATE F., FERRAZZOLI P., PALOSCIA S., PAMPALONI P. and SCHIAVON G., 1995, SAR polarimetric features of agricultural areas, International Journal of Remote Sensing, 16, 14, pp. $2639-2656$

BATES, P.D., 2004, Remote sensing and flood inundation modeling, Hydrology Processes, 18, pp. 2593 $-2597$. 
BOUMAN, B.A.M. and VAN KASTEREN, H.W.J., 1990, Groundbased X-band (3-cm wave) radar backscattering of agricultural crops. II. wheat, barley, and oats; the impact of canopy structure, Remote Sensing of Environment, 34, 2, , pp. 107 - 119.

CAMMAlleri, C., CiRAOlO, G., LA LOGGIA, G. and MALTESE, A., 2012, Daily evapotranspiration assessment by means of residual surface energy balance modeling: a critical analysis under a wide range of water availability, Journal of Hydrology, 452, pp. $119-129$.

CAPODICI, F., D'URSO, G. and MALTESE, A., 2013, Investigating the Relationship between X-Band SAR Data from COSMO-SkyMed Satellite and NDVI for LAI Detection. Remote Sensing, 5, pp. 1389 - 1404.

DENTE, L., SATAlinO, G., MATTIA, F. and RINALDI, M., 2008, Assimilation of Leaf Area Index derived from ASAR and MERIS Data into CERES-Wheat model to map wheat yield, Remote Sensing of Environment, 112, 4, ,pp. 1395 - 1407.

DEMAREZ, V., DUTHOIT, S., BARET, F., WEISS, M., and DEDIEU, G. 2008. Estimation of leaf area and clumping indexes of crops with hemispherical photographs, Agricultural and Forest Meteorology, 148, pp. $644-655$.

FERRAZZOLI, P., PALOSCIA, S., PAMPALONI, P., SCHIAVON, G., SIGISMONDI, S. and SOLIMINI, D., 1997, The potential of multifrequency polarimetric SAR in assessing agricultural and arboreous biomass, Geoscience and Remote Sensing, IEEE Transactions on, 35,1, pp.5 - 17.

FIEUZAL, R., BAUP, F. and MARAIS-SICRE, C., 2013, Monitoring wheat and rapeseed by using synchronous optical and radar satellite data from temporal signatures to crop parameters estimation, Advances in Remote Sensing, 2, 2, pp. $162-180$.

FREI, U., GRAF, K. C. and MEIER E., 1993, Cartographic reference system. In SAR geocoding. Data and systems, (Berlin, Germany, Wichmann Verlag).

HADRIA, R., DUCHEMIN, B., JARLAN, L., DEDIEU, G., BAUP, F., KHABBA, S., OLIOSO, A. and LE TOAN, T., 2010, Potentiality of optical and radar satellite data at high spatio-temporal resolutions for the monitoring of irrigated wheat crops in Morocco, International Journal of Applied Earth Observation and Geoinformation, 1, 12, pp. S32 - S37.

HOLECZ, F., MEIER, E., PIESBERGEN, J. and NÜESCH. D., 1993, Topographic effects on radar cross section, In CEOS SAR Calibration Workshop, Proceedings on, 20 - 24 September 1993, ESAESTEC, Noordwijk, Netherlands, pp. $23-28$.

JONCKHEERE, I., FLECK, NACKAERTS, K., MUYS, B., COPPIN, P., WEISS, M., BARET, F., 2004. Review of methods for in-situ leaf area index determination. Part I. Theories, sensors and hemispherical photography. Agricultural and Forest Meteorology, 121, pp. 19 - 35.

KROPATSCH W.G and STROBL, D., 1990, The generation of SAR layover and shadow maps from digital elevation models. IEEE Geoscience and Remote Sensing, Transaction on, 28, 1, pp. 98 - 107.

MACElloni, G., PAlOSCIA, S., PAMPAlONI, P., MARLIANI, F. and GAI, M., 2001, The relationship between the backscattering coefficient and the biomass of narrow and broad leaf crops. Geoscience and Remote Sensing, IEEE Transactions on, 39,4, pp. 873 - 884 .

MAlTESE, A., CAMMAlleRI, C., CAPODICI, C., CIRAOLO, G., COLlETTI, F., LA LOGGIA, G., and SANTANGELO, T., 2011, Comparing actual evapotranspiration and plant water potential on a vineyard. In SPIE Remote Sensing for Agriculture, Ecosystems, and Hydrology Conference, Proceedings of, 19 - 22 September 2011, Prague, Czech Republic.

MASON, D.C., SPECK, R., DEVEREUX, B., SCHUMANN, G.J.P., NEAL, J.C. and BATES, P.D., 2010, Flood detection in urban areas using TerraSAR-X, IEEE Geoscience and Remote Sensing, Transaction on, 48, pp. $882-894$.

MEIER E., FREI U. and NUESCH, D., 1993, Precise terrain corrected geocoded images, In SAR geocoding data and systems, (Berlin, Germany, Wichmann Verlag).

MORAN, M.S., HYMER, D.C., QI, J. and SANO, E., 2000, Soil moisture evaluation using multitemporal synthetic aperture radar (SAR) in semiarid rangeland, Agricultural and Forest Meteorology, 105, 1 pp. $69-80$.

PALOSCIA, S., MACELlONI, G., PAMPALONI, P. and SANTI, E., 2004, The contribution of multitemporal SAR data in assessing hydrological parameters, Geoscience and Remote Sensing Letters, IEEE, 1,3, pp. $201-205$.

PALOSCIA, S., PAMPALONI, P., PETTINATO, S. and SANTI, E., 2008, A comparison of algorithms for retrieving soil moisture from ENVISAT/ASAR Images, Geoscience and Remote Sensing, IEEE Transactions on, 46,10, pp. $3274-3284$.

PALOSCIA, S., PAMPALONI, P., SANTI, E., PETTINATO, S., BROGIONI, M., PALCHETTI, E. and CREPAZ, A., 2012, Comparison of COSMO-SkyMed and TerraSAR-X data for the retrieval of land 
hydrological parameters. In Geoscience and Remote Sensing Symposium (IGARSS), IEEE International Proceedings of, 22 - 27 July 2012, Munich, Germany, pp. 5510 - 5513.

PETTINATO, S., SANTI, E., PALOSCIA, S., PAMPALONI, P. and FONTANELli, G., 2013. The intercomparison of X-Band SAR images from COSMO-SkyMed and TerraSAR-X satellites: Case studies, Remote Sensing 5,6, pp. 2928 - 2942.

SANTI, E., FONTANELLI, G., MONTOMOLI, F., BROGIONI, M., MACELLONI, G., PALOSCIA, S., PETTINATO, S. and PAMPALONI, P., 2012, The retrieval and monitoring of vegetation parameters from COSMO-SkyMed images. In Geoscience and Remote Sensing Symposium (IGARSS), IEEE International Proceedings of, 22 - 27 July 2012, Munich, Germany, pp. $7031-7034$.

SANTI, E., PETTINATO, S., PALOSCIA, S., BROGIONI, M., FONTANELLI, G., PAMPALONI, P., MACELLONI, G. and MONTOMOLI, F. 2011, The potential of multi-temporal COSMO-Skymed SAR images in monitoring soil and vegetation. In Geoscience and Remote Sensing Symposium (IGARSS), IEEE International Proceedings of, 24 - 29 July 2011, Munich, Germany, pp. 1532 1535.

SHI, J., WANG, J., HSU, A., O'NEILL, P. and ENGMAN, E.T., 1997, Estimation of bare surface soil moisture and surface roughness parameters using L-band SAR image data, Geoscience and Remote Sensing, IEEE Transactions, 35,5, pp. $1254-1266$.

ULABY, F.T., MOORE, R.K. and FUNG, A.K., (Ed.), 1986, Microwave remote sensing: active and passive, Vol. III - volume scattering and emission theory, advanced systems and applications, (Dedham, Massachusetts, Artech House, Inc.).

ZADOKS, J.C., CHANG, T.T., and KONZAK, C.F., 1974, A decimal code for the growth stages of cereals, Weed Research 14,6, pp. $415-421$.

ZRIBI, M., CHAHBI, A., LILI, Z., DUCHEMIN, B., BAGHDADI, N., AMRI, R. and CHEHBOUNI, A., 2011, Soil surface moisture estimation over a semi-arid region using ENVISAT ASAR radar data for soil evaporation evaluation, Hydrology and Earth System Sciences, 15, pp. 345 - 358. 
Table 1 - Weather and vegetation conditions during the measurement campaigns (BBCH is a scale used to identify the phenological development stages of a plant, developed by Zadoks et al., 1974).

\begin{tabular}{|c|c|c|c|}
\hline Date & Weather & Measurements made & Average vegetation condition \\
\hline 14 March 2012 & $\begin{array}{c}\text { Sunny, } \\
\text { clear-sky }\end{array}$ & SMC, plant geometry & Stem elongation, $\mathrm{BBCH} \cong 3$. \\
\hline 15 March 2012 & $\begin{array}{c}\text { Sunny, } \\
\text { clear-sky }\end{array}$ & SMC & Stem elongation, $\mathrm{BBCH} \cong 3$. \\
\hline 22 March 2012 & $\begin{array}{c}\text { Sunny, } \\
\text { clear-sky }\end{array}$ & LAI & 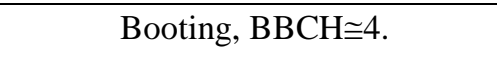 \\
\hline 24 March 2012 & $\begin{array}{l}\text { Sunny, } \\
\text { clear-sky }\end{array}$ & SMC, plant geometry & $\begin{array}{c}\text { Inflorescence } \mathrm{BBCH} \cong 4 \text {. and } \\
\text { heading } \mathrm{BBCH} \cong 5 \text {. }\end{array}$ \\
\hline 25 March 2012 & $\begin{array}{l}\text { Sunny, } \\
\text { clear-sky }\end{array}$ & SMC, plant geometry & $\begin{array}{c}\text { Inflorescence } \mathrm{BBCH} \cong 4 \text {. and } \\
\text { heading } \mathrm{BBCH} \cong 5 \text {. }\end{array}$ \\
\hline 28 March 2012 & $\begin{array}{l}\text { Sunny, } \\
\text { clear-sky }\end{array}$ & SMC, plant geometry & $\begin{array}{c}\text { Inflorescence } \mathrm{BBCH} \cong 4 \text {. and } \\
\text { heading } \mathrm{BBCH} \cong 5 \text {. }\end{array}$ \\
\hline 05 April 2012 & Cloudy & SMC, LAI & (heterogeneity), $\mathrm{BBCH} \cong 4 .-7$. \\
\hline 16 April 2012 & Rainy & SMC, plant geometry & Ripening, $\mathrm{BBCH} \cong 8$ \\
\hline 27 April 2012 & $\begin{array}{l}\text { Sunny, } \\
\text { clear-sky }\end{array}$ & SMC & Ripening, $\mathrm{BBCH} \cong 8$. \\
\hline 04 May 2012 & $\begin{array}{l}\text { Sunny, } \\
\text { clear-sky }\end{array}$ & LAI & 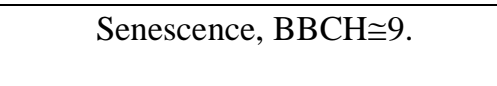 \\
\hline 09 May 2012 & $\begin{array}{c}\text { Sunny, } \\
\text { clear-sky }\end{array}$ & SMC & 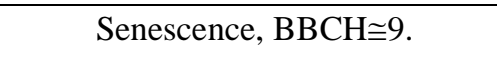 \\
\hline 18 May 2012 & Cloudy & SMC & Senescence, $\mathrm{BBCH} \cong 9$ or harvested \\
\hline 29 May 2012 & Cloudy & SMC & Harvested \\
\hline 30 May 2012 & Cloudy & SMC & Harvested \\
\hline
\end{tabular}

Table 2 - Characteristics of the SAR images acquired on the Merguellil during the measurement campaigns

\begin{tabular}{|l|c|c|c|c|c|}
\hline Date & Sensor & Product & $\begin{array}{c}\text { Incidence } \\
\text { angle } \mathbf{(}^{\circ}\end{array}$ & $\begin{array}{c}\text { Polarizat } \\
\text { ion }\end{array}$ & $\begin{array}{c}\text { Satellite } \\
\text { pass }\end{array}$ \\
\hline 14 March 2012 & TerraSAR-X & Spotlight & 35.3 & HH & Ascending \\
\hline 18 March 2012 & TerraSAR-X & Spotlight & 30.2 & HH & Descending \\
\hline 25 March 2012 & TerraSAR-X & Spotlight & 35.3 & HH & Ascending \\
\hline 05 April 2012 & TerraSAR-X & Stripmap & 35.3 & VV & Ascending \\
\hline 08 April 2012 & COSMO-SkyMed & Enhanced Spotlight & 45.5 & VV & Descending \\
\hline 16 April 2012 & TerraSAR-X & Stripmap & 35.3 & VV & Ascending \\
\hline 16 April 2012 & COSMO-SkyMed & Enhanced Spotlight & 45.5 & VV & Descending \\
\hline 24 April 2012 & COSMO-SkyMed & Enhanced Spotlight & 45.5 & VV & Descending \\
\hline 27 April 2012 & TerraSAR-X & Stripmap & 35.3 & VV & Ascending \\
\hline 02 May 2012 & COSMO-SkyMed & Enhanced Spotlight & 45.5 & VV & Descending \\
\hline 08 May 2012 & TerraSAR-X & Stripmap & 35.3 & VV & Ascending \\
\hline 10 May 2012 & COSMO-SkyMed & Enhanced Spotlight & 45.5 & VV & Descending \\
\hline 18 May 2012 & COSMO-SkyMed & Enhanced Spotlight & 45.5 & VV & Descending \\
\hline 19 May 2012 & TerraSAR-X & Stripmap & 35.3 & VV & Ascending \\
\hline 26 May 2012 & COSMO-SkyMed & Enhanced Spotlight & 45.5 & VV & Descending \\
\hline 30 May 2012 & COSMO-SkyMed & Enhanced Spotlight & 45.5 & VV & Descending \\
\hline
\end{tabular}




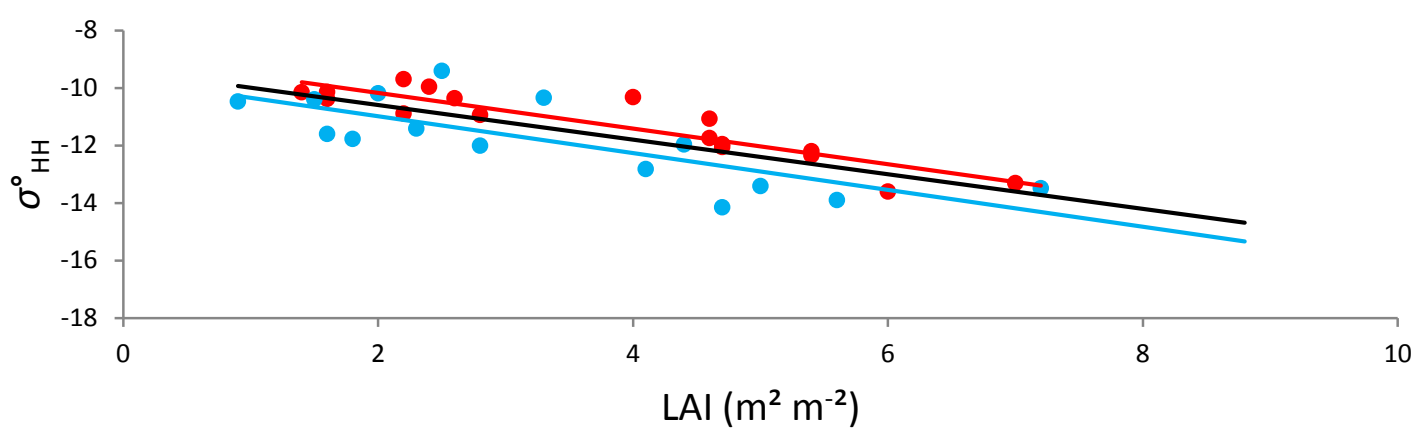

Figure 1 - HH-polarization backscattering values $\left(\sigma_{\mathrm{HH}}^{\circ}\right)$ of TSX data on 14 March 2012 (red dots) and 25 March 2012 (blue dots) versus LAI of barley and wheat crops (plotted together). Lines represent the regression equations and refer to different datasets (red: 14 March; blue: 25 March; black: both datasets).

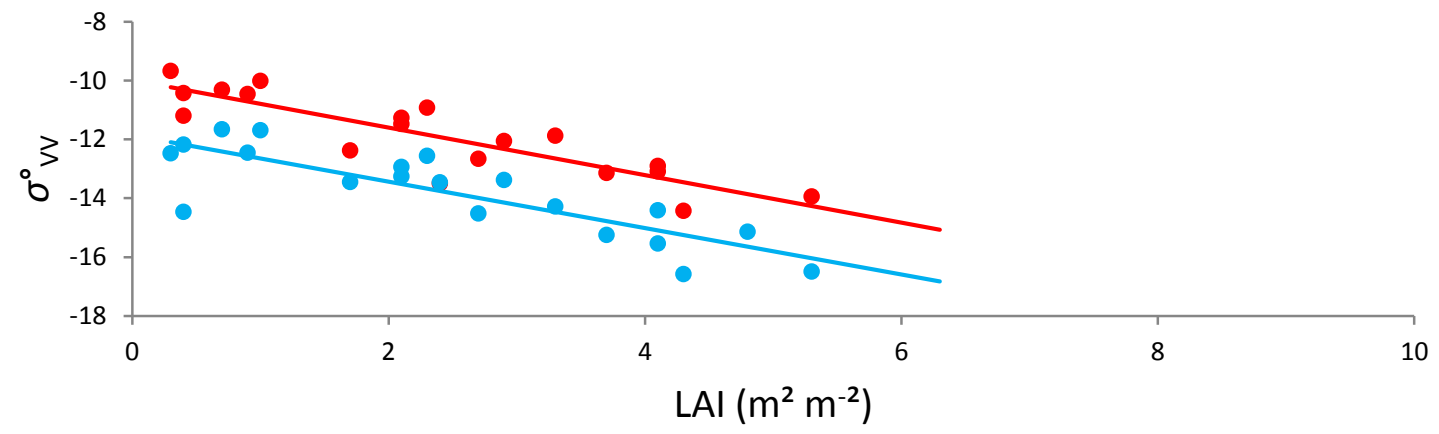

Figure 2 - VV-polarization backscattering values ( $\left.\sigma_{\mathrm{vV}}\right)$ of TSX (red dots), at an incidence angle of $35^{\circ}$ and CSK (blue dots) at $45^{\circ}$, versus LAI of barley and wheat on 16 April 2012. Lines represent the regression equations and refer to different datasets (red: TSX; blue: CSK).

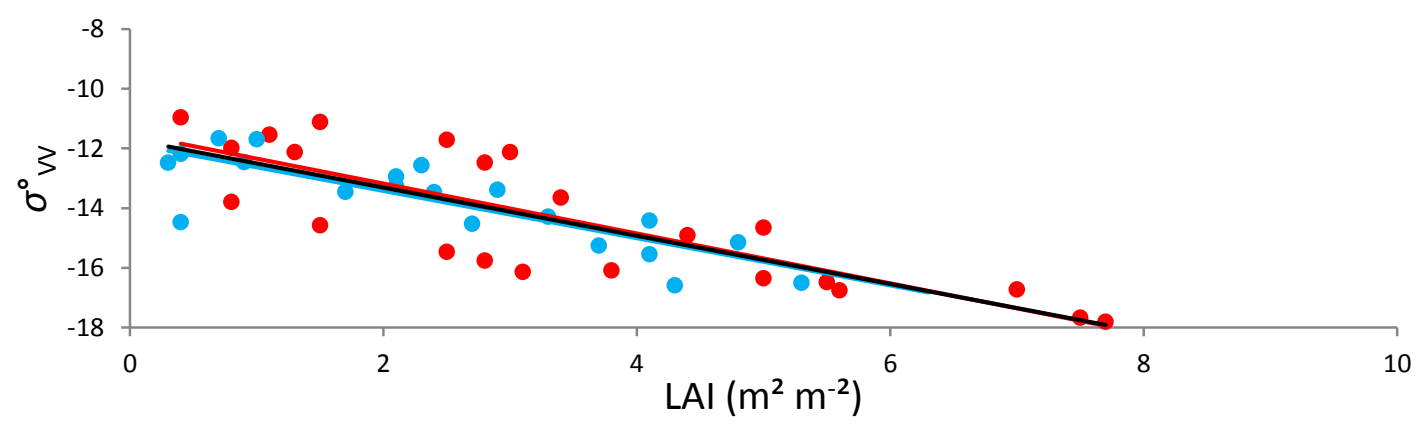

Figure 3 - VV-polarization backscattering values ( $\sigma_{\mathrm{VV}}$ ) of CSK versus LAI of barley and wheat on 08 April 2012 (red dots) and 16 April 2012 (blue dots). Lines represent the regression equations and refer to different datasets (red: 08 April; blue: 16 April; black: both datasets).

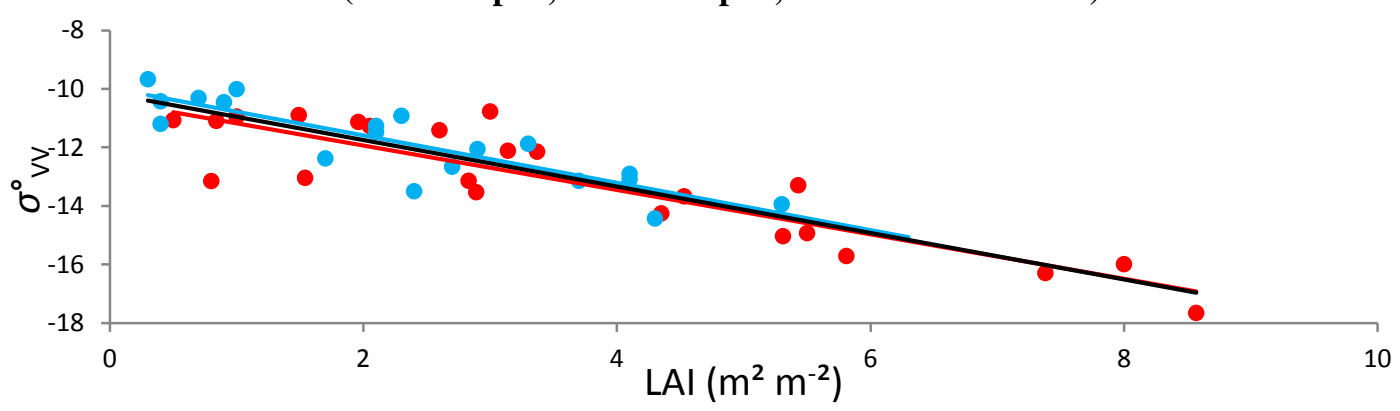

Figure 4 - VV-polarization backscattering values $\left(\sigma_{\mathrm{vV}}^{\circ}\right)$ of TSX versus LAI of barley and wheat on 05 April 2012 (red dots) and 16 April 2012 (blue dots). Lines represent the regression equations and refer to different datasets (red: 05 April; blue: 16 April; black: both datasets). 
